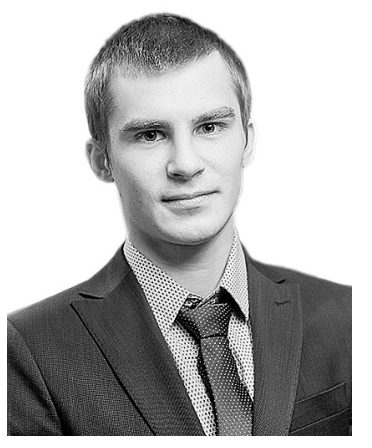

\title{
ІСТОРИЧНЕ МІСЦЕ АДВОКАТУРИ В РОЗВИТКУ СУСПІЛЬСТВІ І ДЕРЖАВИ
}

\section{БАНДУРКА Сергій Сергійович - доктор філософії, адвокат АО «Креденс» DOI 10.32782/LAW.2020.2.2}

\section{У сучасних умовах суспільного життя $i$} державної діяльності, коли захист прав і свобод людини набув не тільки начіонального характеру, а й став міжнародною проблемою, значення і роль адвокатури незмірно зросли.

Права людини, які підлягають захисту, не є досягненням окремої правової системи, вони визначені світовою спільнотою $i$ їх захист передбачений низкою міжнародних правових актів та конкретизований у начіональних правових системах.

Адвокатура, як інститут захисту прав людини, пройшла своє становлення впродовж кількох століть, вона набувала певного міжнародного $і$ начіонального розвитку, власних стандартів, $i$ принципів адвокатськой діяльності, які є ебективними засобами захисту прав і свобод людини .

Виникнення адвокатури, як правового $i$ суспільного явища, було відповіддю на потребу розв'язання суспільних конфліктів, протидію прав людини і незаконним посяганням держави на суспільні інтереси та інтереси окремих громадян. Адвокатура впродовж усъого періоду свого функціонування удосконалювалась, розвивалася ї̈ мережа, вона освоювала нові форми правової регламетизациї та правової доктрини.

Виявлення досвіду адвокатсъкої діяльності минулих часів буде корисним для адвокатури сучасності.

Історія адвокатури Украӥни є невід'ємною частиною історії України, оскільки без виявлення і врахування досвіду адвокатури, ї̈ формування, місия $i$ ролі в суспільному житті, неможливий розвиток України як суверенної, демократичної і правової держави.

Історичні етапи становлення украӥнсъкої адвокатури склали те правове підгрунтя та організачійні засади діяльності адвокатури, методи якої встановлені Законом України « Про адвокатуру та адвокатсъку діяльність».

Інститут адвокатури має тривалу історію і традициї, він зазнав значного впливу правових систем інших держав до складу яких у минулому входили українсъкі землі. Але адвокатура не тільки зазнавала впливу держави, вона і сама активно впливала на подї, що мали місце в суспільному $і$ державному житті.

Згідно з украӥнсъким законодавством про адвокатуру, на ней, як на правовий інститут, покладається важливе завдання професійного захисту інтересів фбізичних $i$ юридичних осіб.

у зв'язку з изм постае необхідність дослідження історичного місия адвокатури в розвитку суспільства $і$ держави.

Ключові слова: адвокатура, адвокатсъка діяльність, правовий захист, права і свобода людини, суспільство і держава, історія.

\section{Вступ}

Зміни суспільних відносин і реформування правової системи України, які відбуваються постійно, ускладнюють фізичним і юридичним особам орієнтування в сучасному законодавстві, можливість використовувати його положення для захисту своїх прав, свобод та законних інтересів. Будучи правозахисником, адвокат стає на бік зако- 


\section{Теорія, історія держави і права, конституційне право}

ну, діючи на його основі і на його виконання.

Виходячи 3 того, що 3 одним із основних завдань адвокатури України є надання кваліфікованої юридичної допомоги, громадянам і юридичним особам та сприяння в охороні прав і законних інтересів громадян i юридичних осіб, виконання якого пов'язано 3 впливом адвокатури на розвиток і реалізацію суспільних відносин, актуальним постає питання про роль і місце адвокатури в розвитку суспільства і держави.

Завдання і мета статті полягають у тому, щоб розглянути історичне місце адвокатури в розвитку суспільства і держави, показати історичні етапи у виникненні, становленні і розвитку адвокатури, її вплив на суспільні процеси та правові підстави для взаємодій адвокатури і державних органів в системі захисту прав і свобод людини в Україні.

Стан наукової дослідженості історичного місця адвокатури в розвитку суспільства і держави.

Історичне місце адвокатури в розвитку суспільства і держави досліджувалось окремими українськими вченими, зокрема, Святоцький В.О. (Інститут адвокатури України: становлення і розвиток - дисертація, 2010 р.), Тацій Л.В. (Юридична природа адвокатури в системі захисту прав i свобод людини і громадянина - дисертація, 2008 р), Грицюк I.В. (Міжнародно-правові стандарти захисту прав людини в контексті реалізацій права на правову допомогу адвоката - стаття, 2018 р.), Ірина Василик (Сторінки української адвокатури - стаття, 2014 р) М.В Никифорак (Адвокатура на Буковині в період іï перебування в складі Австрії - стаття, 2016 р), окремі факти із історії становлення адвокатури розглядали Н.С. Старченко, С. Довбищенко, С. Блащук, Д. Ващук та інші.

Міжнародно-правовим стандартам організації та діяльності адвокатури були присвячені монографія О.Д. Святоцького та В.В. Медведчука «Адвокатура: історія і сучасність», «Сучасні системи адвокатури» монографія за редакцією О.Д. Святоцького, монографія В.І. Шишкіна «Судові системи світу», докторська дисертація I.В. Назарова «Судові системи країн Свропейського Союзу та України: порівняльно-правовий аналіз». Окремі аспекти адвокатської діяльності розглядалися також такими авторами, як М.О. Баймуратов, С.В. Шевчук,М.В. Буроменський, О.I. Безпалова та іншими.

Вказані вчені зробили важливий внесок у дослідження адвокатської діяльності в Україні, але, на погляд автора, історичне місце адвокатури в розвитку суспільства i держави потребує додаткового висвітлення.

\section{Виклад основного матеріалу}

Адвокат, як термін, походить від латинського «advokatus» - від «advoko» - «запрошую» «закликаю». У Древньому Римі вільним громадянам було надане право представляти себе в суді, або в органах влади як особисто, так і через представника, якого «запрошували» до участі у справі, в переговорах, в іншому спілкуванні.

Таких «запрошених» називали «адвокат», перш за все, так називали родичів i друзів позивача, яких він запрошував на суд. Пізніше в Римській імперії цей термін став застосуватися до судових захисників.

Як професійна діяльність, адвокатура виникла майже разом із судом, який, розглядаючи складні цивільні чи кримінальні справи, потребував участі незалежного від суду, але зацікавленого в розгляді справи спеціаліста, попри те, як він називався.

Правозахисництво виникло в результаті розподілу праці, в процесі якого виникли окремі сфери суспільного життя, професії і види спеціальної, відокремленої діяльності. Розвиток і удосконалення діяльності адвокатури йде паралельно 3 розвитком правового суспільства, виданням законів, створенням судів, виникнення державного примусу в особі правоохоронних органів.

«Не можна сподіватися» як зауважує Форент, «знайти в сучасній цивілізації будь-яке формальне визнання необхідності адвокатури, як окремого ремесла чи про- 
фесії. Подібне визнання можливе тільки на високому розвитку юридичного життя, коли знання права стали недоступними для більшості. Особливий розвиток адвокатура отримала в Стародавній Греції, в Римській Імперії, у Візантії.

На перших ступенях розвитку суспільства ще не можна зустріти адвокатуру в різних країнах того часу, зокрема Египту, Iндії, Риму, Греції чи Візантії, в тому вигляді, в якому вона існує в цей час у європейських народів, чи в інших розвинутих країнах Азї, Америки, Африки та Австралії. Як і всі суспільні установи, такі як, держава, суд, прокуратура, поліція, органи виконавчої влади, місцевого самоврядування, адвокатура не виникла відразу в організаційному вигляді, а з'явилася спочатку в невиразних формах, які пізніше при розвитку суспільства і держави, набули, ознак правозахисної і правоохоронної діяльності.

В адвокатурі Стародавньої Греції і Римської імперії особливого значення набуло красномовство, оскільки судді і інші учасники процесу мало розумілися в юриспруденції, то переконання словом, тлумачення фактів, роз'яснення тих чи інших доказів, вміння говорити стали підставами досягнення бажаного результату. Невміння позивача красиво, образно і переконливо говорити приречувало справу на програш. Оскільки не всі учасники процесу вміли красиво говорити, то для них заздалегідь писались промови, які проголошувались у суді.

Такі промови носили назву «логографії», вони готувалися для рідних і близьких осіб, а потім їх створювання стало професією для певного кола людей, які цими творами займалися професійно і авторів логографії стали називати логографами. Аогографії, як форма захисту в Древній Греції, були розповсюджені і проіснували до кінця республіки.

Ораторське мистецтво не могло задовольнити потребу суду в знаннях законів, у правильній оцінці доказів та інших фактичних даних, які пред'являлися суду. в зв'язку з цим, суди дозволили в окремих випадках, крім особистого захисту, участь інших осіб, які розумілись на нормах зако- ну чи достатньо розбирались у класифікації ситуацій. За таких обставин, перед письмовими промовами (логографією) виник усний захист на запрошення потерпілого позивача. Така участь спочатку стосувалася родичів і близьких, а потім і на договірних засадах, що привело до формування адвокатури Древньої Греції, образно кажучи, в первісному стані.

Древня Греція припинила своє існування коли потрапила під владу Риму в V ст. до н. е. Римляни започаткували свої судові установи і тільки, як особливу милість, надавали грекам право брати участь в здійсненні правосуддя. Правовий лад Греції був перетворений згідно з римськими законами і історією римського права, в т.ч. і адвокатура злилася з римською історією.

В історії адвокатури Римської імперії особливе значення мав кодекс Юстініана прийнятий в III ст н.е., що представляв собою узагальнення всього попереднього законодавчого розвитку римської держави. У кодексі Юстініана було закладено основи римської адвокатури, основним принципом якої було віднесення професії адвоката до посадової служби. Професійні адвокати носили назву стану (ordo).

Вперше адвокати, як професійні діячі, з'явились у Древньому Римі. Як зазначав історик E.В. Васильковський «першими юристами в Римі були патрони. У їх особах 3'єднувались дві професії: юрист-консультантів і адвокатів». Тривалий час послуги адвокатів виконували оратори, які часто не були знавцями права. Відомий римський політик Ціцерон, сам талановитий оратор, нещадно критикував таких адвокатів. Адвокатура республіканського періоду Древнього Риму була вільною професією i організаційного устрою не мала. Колегія професійних захисників у суді сформувалася в Римі, в епоху імперського правління. Документально зафіксована Колегія враховувала юристів-захисників, занесених в офіційний список людей $з$ певними матеріальними доходами та успішно складеними іспитами із знання справи. Організація адвокатури, яка склалась в епоху імперії, була класична. Вона стала основою всіх наступних формувань адвокатури, від того часу до 


\section{Теорія, історія держави і права, конституційне право}

новітнього часу. Досвід створення і діяльність адвокатури, як об'єднання професійних захисників, якими володів Рим, поширилися, а потім були запозичені і іншими країнами, які виникли на розвалинах Римської імперії.

Як стверджує Ірина Василик, зародження в минулому на нинішніх українських землях правової системи, і, відповідно, адвокатури відбулося, починаючи від міст держав Північного Причорномор'я як носіїв римської правової традиції та Київської Русі, в часи якої захисниками у судах могли бути «послухи», «видоки», здебільшого рідні, друзі, члени однієї громади.

Вперше інститут захисту та представництво згадується у фіксованих законодавчих актах у кінці XIV - початку XV ст. - у Псковській та Новгородській судних грамотах, які були чинними на окремих територіях нинішніх українських земель.

У XV ст. на українських землях відбувається поступовий розвиток професійної адвокатури, що зумовлювалось поширенням магдебурзького права та утворенням міських судів. У цей період поняття «адвокат» ще не мало визначеного терміну, використовувався термін «посол», найчастіше - «прокуратор», що є аналогічним відповідним назвам у німецьких правових пам 'ятках.

Фактичне становлення інституту адвокатури українського зразка відбулось у литовсько-польську добу XVI-XVIII ст. У I Аитовському Статуті (1529р.) вказувалось «заступництво у речах» $\mathrm{i}$ «приятель»; у другому Аитовському статуті (1566) - «речник», «умовленний», «поручник». У Великому Литовському князівстві, до складу якого в XVI - XVII ст. входила більша частина українських земель, судова система як на той час була досить розвинутою, що обумовлювало і розвиток правозаступництва.

Функції адвокатів у XVI ст. виконували «поленіпотенти», обслуговуючи своїх родичів або друзів. У середині XVII ст. на Волині вже існувала сформована група професійних правників, які вели в судах справи впливових політичних та духовних осіб держави і самі відігравали помітну роль у суспільно-політичному житті Волині, Речі
Посполитої та козацької України. Адвокати того часу: Прокіп Верещака - сподвижник гетьмана Івана Виговського та один із вірогідних співавторів Гадяцького договору (1658). Федір Бонякевич, Томаш Гуляницький. Адвокатські династії Верещаків (Прокіп, Максиміліан); Виговських - Миколай i Федір виконували функції пленіпотентів у князя Андрія Пузини та у Ауцького православного єпископа.

Починаючи з XVII ст., з'явилось поняття «стряпчий», яке означало чин деяких службових осіб, що виконували різноманітні господарські обов'язки при царському дворі. У XVIII ст. це був урядовець при губернських прокурорах, що здійснював судовий нагляд у повітах Росії. 3 XIX ст. це була особа, допущена до адвокатської практики в комерційних судах. Особливу категорію становили монастирські і архієрейські стряпчі, які крім чернечої діяльності, виконували різні доручення, пов'язані із матеріальними інтересами обителі чи цілої єпархії.

У Новгородській судній грамоті повіреного міг мати всякий учасник процесу i в разі наявності в них представників у судовому процесі, повинні були мати справу тільки 3 ним (ст. 5). У статті 36 Судебника (1497) Московського царства, було передбачено, якщо позивач або відповідач самі не прибули в суд, то вони мали право надіслати замість себе повірених. Наступний Судебник, 1550 року, у ст. 13 закріплював не тільки право сторін мати повірених (стряпчих і поручників), але і встановлював певні правила для проведення поєдинку. Тобто Судебники 1497 і 1550 року, а так само Coборне Положення 1649 року, наявність найманих повірених згадують уже як наявне явище. Разом з тим, законодавчої регламентації представництва (стряпчества) не було, і склад цих осіб був досить різноманітний. Лише судова реформа 1864 року заклала в Російській імперії основи компетентної та самоврядної організації адвокатів. Адвокати того часу підрозділялися на дві групи: присяжних повірених, які забов' язані були давати професійну присягу адвокатів, які перебували у корпорації, і приватних по- 
вірених, які займалися адвокатською практикою тільки індивідуально.

Присяжні повірені грали серед адвокатів провідну роль і набиралися з найбільш освіченої частини російської еліти. Професійні об'єднання присяжних повірених організовувалися за територіальною ознакою.

Присяжні повірені об'єднувалися в особливу корпорацію - стан присяжних повірених 3 внутрішнім самоврядуванням у вигляді виборних органів (рад присяжних повірених). У завдання адвокатури, крім захисту у кримінальних справах, входило представництво сторін у цивільному процесі та надання юридичної допомоги населенню, включаючи безкоштовні консультації для бідних.

Законом було встановлено, що присяжними повіреними могли бути особи, які досягли 25-літнього віку, та закінчили університетський курс юридичних наук і мали п’ять років судової практики як чиновника судового відомства або помічника присяжного повіреного. У другій половині ХІХ ст. існував також інститут помічників присяжних повірених. Ними могли бути особи, які отримали юридичну освіту, але ніде не служили. Як органи самоврядування корпорації присяжних повірених, діяли Ради присяжних повірених. Вони складалися 3 голів, товаришів голови та членів ради, чиї посади були виборними.

Рада присяжних діяла у різних напрямках: приймала і звільняла присяжних повірених, здійснювала дисциплінарну практику, розподіляла «безкоштовні» справи серед присяжних повірених, регулювала різні суперечки між ними і т.д. Діяльність ради контролювалася судовою палатою. 6 червня 1874 р. у Російській імперії був виданий закон, який заснував разом 3 присяжною адвокатурою інститут приватних повірених. Підставою для затвердження на посаді приватного повіреного та отримання права на участь у виробництві цивільних справ у мирових суддів і в загальних судових установах було отримання особливого свідоцтва, яке видавали тим судом, в окрузі яких приватний повірений здійснював клопотання по справах.
Відмінність присяжних повірених від приватних повірених полягало в тому, що присяжні повірені зберігали право клопотати у всіх судових місцях Російської імпеpiï, а приватні повірені могли виступати тільки в судах, що видали їм такий дозвіл. Інститут присяжних і приватної адвокатури в Російській імперії проіснував до листопада 1917 року, коли в результаті жовтневого перевороту була ліквідована вся правова система Росії.

Згідно 3 Декретом «Про суд» № 1 від 24 листопада 1917 року, крім присяжної адвокатури, скасовувалися інститут прокуратури, відділи кримінальних розслідувань i взагалі практично вся судова система. I якщо більшість юридичних установ повинна було швидко реорганізуватися на революційних засадах, то для присяжної адвокатури законодавство заміни не передбачало, воно просто ліквідувало. Представництво в суді було дозволено будь-кому, хто володіє цивільними правами, громадянину будь-якої статі. Тобто адвокатура знову ставала вільною професією, що відкинуло іiі за рівнем організаційного статусу до дореформеного 1864 року. Інструкція про революційні трибунали від 19 грудня 1917 року є першим офіційним актом нової влади, який містив спробу створення нової - радянської адвокатури.

11 травня 1920 року Раднаркомом видається постанова «Про реєстрацію осіб 3 вищою юридичною освітою», згідно з якою у триденний термін після опублікування цієї постанови зазначені особи зобов'язані зареєструватися у підвідділах обліку й розподілу робочої сили за місцем проживання. Особи, не зареєстровані в зазначений термін, вважалися дезертирами і каралися судом. Таким чином, діяльність адвокатів була заміщена формою трудової повинності. Повне знищення, навіть тієї подібності адвокатської корпорації, якою була колегія правозахисників, відбулося прийняттям 21 жовтня 1920 року ВЦВК доповнень до По^оження «Про народний суд РСФСР», що спричинило за собою розвиток підпільної адвокатури. Діяльність адвокатури, на яку не впливала влада, не влаштувала їі, тому на четвертому Всеросійському з’їзді діячів 


\section{Теорія, історія держави і права, конституційне право}

радянської юстиції, народний комісар юстиції Д. Курський визначив перспективи розвитку адвокатури: «Або ми створимо організацію адвокатів, яка буде знаходитися під нашим контролем, або візьме верх приватна практика». I саме на цьому з’їзді була запропонована для обговорення реформа, що стосувалася адвокатури. 25 травня 1922 року приймається Положення «Про адвокатуру», але оскільки воно лише в загальних рисах описувало новостворювану колегію захисників, то Нарком'юстом 5 липня 1922 року було прийняте Положення «Про колегії захисників», згідно з яким такі колегії утворювалися при губернських судах, а нагляд за їх діяльністю покладався на суд, виконком та прокуратуру. Значна кількість членів нових колегій були так званими буржуазними фахівцями - членами професійної корпорації, що одержали освіту при царському режимі. Цифри за 1923 рік свідчать, що приблизно 75\% усіх фахівців, які вступили в колегії, отримали вищу юридичну освіту в царських навчальних закладах.

22 грудня 1938 року Наркомюст СРСР видав директиву «Про роботу колегій захисників», яка, на думку М.В. Іванової, поклала початок кампанї̈ з остаточної трансформації адвокатури радянських установ.

Нове Положення про адвокатуру 1939 року було моделлю для всіх наступних законів про корпорації адвокатів. Адвокатам заборонили поєднувати роботу в держустановах на повну ставку з роботою в адвокатурі, що змусило їх вибирати між роботою в держсекторі і роботою в адвокатурі.

Нагляд за діяльністю адвокатури з боку державних органів був переданий Наркомату юстиції СРСР, республіканським Наркоматам юстиції і регіональним управлінням нарком'юсту. Крім здійснення наглядових функцій і ролі останньої інстанції при вирішенні питань складу та професійної дисципліни ці органи періодично видавали обов'язкові до виконання колегіями адвокатів директиви з організації їх діяльності.

Адвокатура, як самоврядна організація, у значній мірі втратила цю важливу властивість у радянський період. Проведені в цей період перетворення корпорації викликалися скоріше не прагненням удосконалити цей інститут, як правозахисну організацію, а наміром законодавця створити керовану органами держави структуру, що вписується в новий громадський та державний лад. У період з 1960 року по 1962 рік союзні республіки, в тому числі і Україна, прийняли нові Положення про адвокатуру.

У відповідності зі ст. 1 Положення колегії адвокатів визначалися як добровільні об'єднання осіб, які займаються адвокатською діяльністю, організаційною формою якої були лише юридичні консультації, тобто можливості займатися приватною практикою, вказане Положення не передбача^o.

У грудні 1970 року ЦК КПРС і Ради Міністрів СРСР прийняли спільну постанову «Про поліпшення правової роботи в народному господарстві». Адвокатура у звязку 3 цим несла значне навантаження в правовому обслуговуванні підприємств, установ, радгоспів і колгоспів, у яких відсутня юридична служба.

Таким чином, упродовж усього періоду свого розвитку, від зародження у вигляді стряпчества, до цілком сформованного i невід'ємного інституту громадянського суспільства демократичної держави, адвокатура в нашій країні пройшла (і проходить, на сьогодні) складний шлях становлення і розвитку. Aле історія адвокатури триває, як правозахисного інституту, і хід її неможливо зупинити.

У 1972 році вперше в історії радянської адвокатури, іiі правове становлення було закріплено в ст. 161 Конституції СРСР. У 1979 році Верховною Радою СРСР був прийнятий Закон СРСР «Про адвокатуру в СРСР». Законом були встановлені основні засади організації та діяльності адвокатури в загальносоюзному масштабі. Відповідно до Закону в союзних республіках були прийняті республіканські Положення про адвокатуру. 1 жовтня 1980 року було прийняте і Положення про адвокатуру УРСР.

За Конституцією УРСР 1978 р. обвинуваченому забезпечувалося право на захист, в окремих випадках допомога громадянам надавалася безкоштовно. Проте, в умовах 
діï Кримінально-процесуального кодексу СРСР від 1960 р. адвокати здебільшого допускалися до справи на стадії складання обвинувачувального висновку і були позбавлені прав у наданні доказової бази. У цьому контексті становище адвокатури в цілому та захист адвокатами українських дисидентів, інакомислячих тощо, потребує окремого дослідження.

В роки української незалежності 19 грудня 1992 року Верховною Радою України прийнято із Законом «Про адвокатуру»(№ 2887-XII). Згідно Закону, адвокатура України є добровільним професійним громадським об'єднанням, покликаним сприяти захисту прав, свобод і представляти законні інтереси громадян України, іноземців, осіб без громадянства, юридичних осіб, надавати їм різну юридичну допомогу. Адвокатура України здійснюе свою діяльність на принципах верховенства закону, незалежності, демократизму, гуманізму і конфіденційності. Стаття 19 Закону відкрила можливість для створення спілок та організацій, які представляють інтереси адвокатури у державних органах і об'єднаннях громадян, захищають соціальні та професійні права адвокатів, здійснюють методичну і видавничу роботу, сприяють підвищенню професійного рівня адвокатів, можуть створювати спеціальні фонди і діють відповідно до своїх статутів.

5 липня 2012 р. Верховна Рада України прийняла новий Закон України «Про адвокатуру і адвокатську діяльність». Закон впорядковує організаційні умови діяльності адвокатури. Стаття 5 Закону визначає, що «адвокатура $є$ незалежною від органів державної влади, органів місцевого самоврядування, їх посадових та службових осіб. Держава створює належні умови для діяльності адвокатури та забезпечує дотримання гарантій адвокатської діяльності Відповідно до Закону, 17 листопада 2012 р. утворено професійну організацію адвокатів національного рівня - Національну асоціацію адвокатів України», як найвищий орган адвокатського самоврядування. Вона об’єднує всіх адвокатів України з метою забезпечення реалізації завдань адвокатського самоврядування. Асоціація створена на засадах професійної належності для сприяння розвитку та зміцнення інституту адвокатури в Україні, підвищення рівня правової допомоги, що надається адвокатам, ролі та авторитету адвокатури в суспільстві, захисту прав і законних інтересів їі членів.

\section{Висновки}

Адвокатура України формувалася тривалий час від Київської Русі до сучасності. Вплив на становлення правозхисництва на українських землях мали правові системи тих держав, до складу яких вони входили. Aле і адвокатура, незалежно від того, як вона називалась, захищаючи справедливість, встановлюючи істину, спонукаючи інших суб'єктів права до додержання законів, впливала на формування суспільства i розвиток держави. Адвокатура сприяла поширенню правової свідомості, впровадження в правоохоронну i правозахисну діяльність професійної юридичної етики, поваги до правових норм, контролюючи їх виконання. В незалежній Україні адвокатура є розвинутим інститутом захисту прав i свобод людини, законних інтересів суспільства і держави. На адвокатуру покладаються і суспільно важливі завдання професійного правового захисту всіх представників громадського суспільства. Ефективне виконання адвокатурою своїх завдань з надання правової допомоги неможливе без знання іiі історії і врахування досвіду минулих років.

\section{Мітература}

1. Василик Ірина Сторінки історії української адвокатури : доповідь на міжнародній науковій конференції, Київ, 2018 рік

2. Ващук Д. Вплив обласних привілеїв Київщини та Волині на формування Першого Аитовського Статуту // Україна в Центрально-Східній Европі (з найдавніших часів до кінця XVIII ст.). - Вип. 4. Київ 2004. - С. 177-194.

3. Калюжний Р., Дорошенко Ю. Нарис історії київського правничого (юридичного) товариства // Український Правничий Альманах. - Київ 2002. - С. 224-243.

4. Петрів М. Історія української адвокатури в Польщі: Союз українських адво- 


\section{Теорія, історія держави і права, конституційне право}

катів у Аьвові - 1923-1940 pp. / М. Петрів // Адвокат. - 2002. - № 4-5.

5. Усенко I. Юридичні товариства // Юридична енциклопедія: В 6 т. / Редкол.: Ю. Шемшученко (відп. ред.) та ін. - Т. 6: Т-Я. - Київ 2004.

6. Закон України «Про адвокатуру та адвокатську діяльність» від 05.07.2012 №5076-VI. - Верховна Рада України // Інтернет-джерело: http://zakon1.rada.gov.ua/ laws/show/-5076-17.

7. Офіційний сайт Національної Асоціації Адвокатів України. - Інтернет-джерелo: http:- //unba.org.ua/abo.

8. Історія адвокатури України (2 видання): // Редкол.: В. В. Медведчук (голова) та інші - Київ 2002. - 286 с. - С. 23.

9. Конституція (Основний Закон) Української Радянської Соціалістичної Республіки Прийнята позачерговою сьомою сесією Верховної Ради Укр. РСР дев'ятого скликання 20 квіт. 1978 р. - Київ 1979. - 69 c. - C. 58 .

10. 17 Redzik A., Kotliński T. Historia Adwokatury. - Naczelna Rada Adwokacka, Ośrodek Badawczy Adwokatury im. Witolda Bayera / A. Redzik, T. Kotliński. - Redakcja «Palestry», Warszawa. - 2012.
In the modern conditions of public life and state activity, when the protection of human rights and freedoms has become not only a national issue, but also an international problem, the importance and role of the Bar has grown immeasurably.

Human rights that are subject to protection are not an achievement of a separate legal system, they are defined by the world community, and their protection is provided for in a number of international legal acts and is specified in national legal systems.

The Bar as an institution of protection of human rights has passed its formation within several centuries; it acquires certain international and national development, its own standards and principles of advocacy which are effective means of protection of human rights and freedoms.

The emergence of the Bar as a legal and public phenomenon was a response to the need to resolve public conflicts, to counteract human rights violations and illegal encroachments by the state on public interests and the interests of individual citizens. Throughout the whole period of its functioning, the Bar has been improving, its network has been developing, it has been mastering new forms of legal regulation and legal doctrine.

The study of the experience of advocacy of the past times will be useful for the modern bar.

The history of the Bar of Ukraine is an integral part of the history of Ukraine, because without revealing and taking into account the experience of the Bar, its formation, place and role in public life it is impossible to develop Ukraine as a sovereign, democratic and legal power.

Historical stages of formation of the Ukrainian Bar created that legal support and activity of organizational bases, methods of which are established by the Law of Ukraine "On advocacy and advocacy activity".

The Institute of Advocacy has a long history and traditions; it has been significantly influenced by the legal systems of other states, which in the past included Ukrainian lands. But the Bar was not only influenced by the state, it also actively influenced the events that took place in public and state life.

According to the Ukrainian legislation on the Bar, as a legal institution it is entrusted with the important task of professional protection of individuals and legal entities.

This makes it necessary to study the historical place of the Bar in the development of society and the state. 